\title{
ANALISIS PENGGUNAAN SUFIKS TEKI DALAM BAHASA JEPANG
}

\author{
L. A. Sumarini ${ }^{1}$, G. S. Hermawan ${ }^{2}$, K. E. K. Adnyani ${ }^{3}$ \\ ${ }^{123}$ Jurusan Pendidikan Bahasa Jepang, Universitas Pendidikan Ganesha, Singaraja,Bali \\ e-mail: anggisumarini@gmail.com \\ satya.hermawan@undiksha.ac.id krishna.adnyani@undiksha.ac.id
}

\begin{abstract}
Abstrak
Penelitian ini bertujuan untuk mengetahui bentuk nomina yang dapat melekat pada sufiks teki. Subjek penelitian ini adalah beberapa majalah Her Story edisi Februari hingga Juni dan koran Chuunichi Shinbun edisi 24 Februari 2017. Pengumpulan data dilakukan dengan studi simak dan catat dan kemudian dianalisis dengan menggunakan metode deskriptif kualitatif. Hasil penelitian ini menunjukkan bahwa dalam beberapa seri majalah koran Her Story dan Chuunichi Shinbun edisi 24 Februari 2017 ditemukan sebanyak 23 kata bersufiks teki yang dilekati bentuk nomina biasa (Futsuu meishi), sebanyak 1 kata bersufiks teki yang dilekati bentuk nomina nama diri (koyuu meishi), dan sebanyak 3 kata bersufiks teki yang dilekati bentuk nomina bilangan (Suushi meishi), dan tidak ditemukan bentuk nomina nama diri (Koyuu meishi) dan bentuk nomina kata ganti (Dai meishi).
\end{abstract}

Key words: sufiks, nomina, majalah Her Story edisi Februari hingga Juni 2012, koran Chuunichi Shinbun edisi 24 Februari 2017

\section{要旨}

本研究の目的は的の接尾にどのような名詞が付けることが出来るのを知るためである。調査対象は2 月版から6月版まで「ハーストーリー」雑誌、及び2017年2月24日版の中日新聞である。データ収集は 観察、及び文章化でそれを定量的な記述法によって分析した。調査結果は「ハーストーリー」雑誌版 、2017年2月20日版中日新聞では普通名詞に付けらた的の接尾は23個、固有名詞付けられた的の接尾 は1個が発見された数詞名詞に付けられた的の接尾は3個が発見された。ところが代名詞の場合は接尾 がないと分かった。

キーワード : 接尾、名詞、2月版から6月版まで「ハーストーリー」雑誌、2017年2月24日版の中日新聞

\section{Pendahuluan}

Istilah morfologi dalam bahasa Jepang dikenal dengan nama keitairon. Morfologi merupakan cabang ilmu linguistik yang mengkaji atau mempelajari tentang proses pembentukkan kata.

Koizumi (1993:89) menyatakan, 形態論は語形の分析が中心となる。Keitairon wa gokei no bunseki ga chuusin to naru. Morfologi adalah satu bidang ilmu yang meneliti pembentukan kata.

Batasan proses morfologi adalah proses pembentukan suatu kata yang sudah ada menjadi bentuk yang lain. Proses ini dapat terjadi dengan cara penambahan, penghapusan dan imbuhan kosong. Proses morfologi pada umumnya dibagi menjadi beberapa proses, yaitu derivasi, afiksasi, reduplikasi, komposisi, dan perubahan vokal

Secara umun proses afiksasi dalam sebuah bahasa terdiri dari prefiks, sufiks, dan infiks. Namun dalam bahasa Jepang afiksasi hanya digolongkan menjadi dua jenis, yaitu prefiks (settouji), dan sufiks (setsubiji). Hal ini disebabkan karena sangat jarang ditemukan kosakata bahasa Jepang yang dibubuhi infiks. Dan dalam afiksasi keberadaan afiks tentu sangat dibutuhkan.

Afiks memiliki peran yang sangat penting dalam bahasa Jepang. Dalam pembentukan kata afiks melekat pada kelas kata yang berbeda dan juga dapat mengubah kelas kata yang dilekatinya. Afiks bisa melekat di depan kata dasar yang disebut dengan prefiks, kemudian 
dapat juga melekat di tengah-tengah kata dasar yang dikenal dengan sebutan infiks, dan afiks yang melekat di akhir kata dasar yang dikenal dengan sebutan sufiks.

Sufiks (setsubiji) pada umumya diartikan sebagai imbuhan pada akhir kata dasar. Sufiks di golongkan menjadi dua jenis, yaitu sufiks yang tidak mengubah kelas kata disebut dengan sufiks infleksional dan sufiks yang dapat mengubah kelas kata disebut dengan sufiks derivisional. Salah satu sufiks yang sering digunakan dalam kosakata bahasa Jepang adalah sufiks $\neg$ teki. Dan tanpa disadarai banyak kosakata bahasa Jepang yang mengandung sufiks, khususnya sufiks teki.

Penulis kerap menjumpai kalimat-kalimat yang didalamnya mengandung kosakata yang mempergunakan sufiks ini di berbagai media cetak, seperti buku pelajaran pelajaran bahasa Jepang, koran Jepang, komik, buku pembelajaran bahasa Jepang serta pada majalah Jepang. Namun dikarenakan keterbatasan waktu penulis hanya mengambil data dari majalah Her Story edisi Februari hingga Juni saja sebagai sumber korpus data.

Her Story merupakan sebuah majalah wanita yang terbit setiap satu bulan sekali dan cukup dikenal di Jepang bahkan di dunia dimana di dalam majalah ini memuat berbagai kisah-kisah inspiratif dari seorang wanita dari berbagai belahan dunia. Her Story merupakan sebuah majalah yang mencerminkan bahwa wanita memegang peranan yang sangat penting dalam perkembangan dunia terlebih pada era emansipasi wanita seperti sekarang ini. Pemilihan seri majalah Her Story yang digunakan karena pada seri inilah paling banyak ditemukan kalimat yang mengandung sufiks teki dan seri-nyapun berurutan, sehingga akan lebih mudah dalam pengumpulan datanya. Selain itu alasan lain dipilinnya majalah sebagai sumber data adalah karena pada majalah bahasa yang digunakan biasanya lebih ringan, sederhana sehingga akan mudah dipahami oleh semua pihak.

Dari permasalahan yang ada maka penulis menganggap perlu adanya pembatasan ruang lingkup permasalahan yang akan dikemukakan. Adapun ruang lingkup pembahasan penelitian ini adalah kajian semantik. Pada penelitian ini permasalahan yang diangkat oleh penulis adalah mengenai jenis nomina yang dapat melekat pada sufiks teki yang terdapat pada majalah Her Story edisi Februari hingga Juni 2012. Kemudian hasil pembentukan kata tersebut akan dikaji secara semantik.

Tujuan dari penelitian ini yaitu untuk mendeskripsikan jenis kata benda apa saja yang dapat melekat pada sufiks teki, untuk mendeskripsikan pembentukan kata dengan sufiks teki dikaji dari morfologi bahasa Jepang itu sendiri, dan untuk mengetahui penambahan sufiks teki pada sebuah kata dasar apakah akan selalu mengubah makna dan kelas kata dari kata itu sendiri.

Penelitian yang dilakukan lakukan saat ini tentunya tidak terlepas dari adanya referensi-referensi penelitian terdahulu yang sejenis. Penelitian terkait kajian morfologi terutama afiksasi suatu sufiks telah banyak dilakukan. Berikut ini adalah beberapa penelitian yang memiliki relevansi dengan penelitian yang penulis lakukan, diantaranya:

Setyawan (2014), membahas mengenai penggunaan sufiks ka, sha, shi, dan in yang bermakana profesi manusia dalam Yomiori Shinbun. Metode yang digunakan dalam penelitian ini adalah metode deskriptif kualitatif. Penelitian ini menganalisis mengenai penyubstitusian sufiks-sufiks tersebut dan didapatkan hasil sebanyak 27 data, yaitu sufiks $\sim$ ka 10 data, sufiks sha 5 data, sufiks shi 6 data, sufiks in 6 data, kemudian dari semua data-data tersebut didapatkan 3 data yang dapat saling disubstitusikan.

Rokhman (2015) membahas mengenai penggunaan prefiks 不 (Fu), 非 (Hi), Dan 無 (Mu) dalam bahasa Jepang. Sumber data pada penelitian ini adalah Asahi Shinbun Edisi 29 Agustus 2014. Penelitian ini memiliki objek penelitian yang sejenis yaitu meneliti tentang afiks, tetapi dengan kategori yang berbeda dengan penelitian-penelitian tersebut di atas yaitu menganalisis mengenai prefiks. Digunakannya penelitian ini sebagai salah satu kajian yang memiliki relevansi dengan penelitian yang akan dibuat adalah karena memiliki kesamaan dalam hal objek penelitian yaitu meneliti tentang afiks, namun di kategori afikas yang berbeda, yaitu sufiks. . Berdasarkan hasil analisis yang dilakukan, maka ditemukan terdapat 68 data yang ditemukan dalam Asahi Shinbun, diantaranya prefiks fu 31data, diantaranya adalah fuantei (tidak stabil), fuhitsuyou (tidak perlu), dan futekitou (tidak layak), prefiks hi 4 data, diantaranya adalah hidoumei (tidak memihak atau bersekutu) dan hibouryoku (anti 
kekerasan) dan prefiks mu 33 data, diantaranya adalah muimi (tanpa arti) dan muishiki (tidak sadar). Dari data-data tersebut terjadi proses afiksasi dan menjadi kata jadian baru, dan dari masing-masing prefiks fu, hi, dan mu terdapat 8 data yang dapat saling disubtitusikan.

Arfan (2014) membahas mengenai makna dan penggunaan kanji 性( sei) dan $\sim$ 的( teki) dalam bahasa Jepang. Di dalam penelitian ini kanji sei dan teki yang memiliki makna karakter manusialah yang menjadi fokus penelitian. Pada penelitian dibahas mengenai proses pembentukan, perbedaan, makna, serta penggunaan kata berakhiran $\sim$ 性( sei) dan 的( teki). Teknik analisis data yang digunakan adalah top down, teknik padan dan teknik balik. Hasil penelitiannya diketahui bahwa kata berkhiran sei yang menyatakan karakter manusia termasuk kelas kata nomina, sedangkan

kata berakhiran teki yang menyatakan karakter manusia termasuk kelas

kata ajektiva na. Contoh kata berakhiran teki yang menyatakan karakter manusia adalah sekkyou teki na, yang berarti 'aktif'dan chiteki na, yang berarti 'pintar'. Sedangkan contoh kata berakhiran sei yang menyatakan karakter manusia adalah tekiousei, yang menyatakan karakter seseorang yang mudah beradaptasi dengan sesuatu yang baru

\section{Metode}

Metode penelitian merupakan bagian yang paling penting dalam suatu penelitian, karena metode penelitian merupakan sebuah jalan atau cara untuk memperoleh kembali pemecahan terhadap gejala permasalahan (Subagyo, 2004:2).

Wendra (2012) mengemukakan prosedur ini mencakup (a) rancangan penelitian, (b) subjek dan objek penelitian, (c) instrumen penelitian, (d) pengumpulan data dan analisis data. Karena dalam bahasa Jepang terdapat banyak sufiks atau setsubiji yang tak jarang menimbulkan kebingungan dalam penggunaannya, maka perlu dilakukan penelitian terhadap setsubiji ini dengan jalan mengumpulkan referensi, menyusun atau mengklasifikasikannya, dan menganalisanya. Dengan kata lain metode penelitian adalah suatu cara pendekatan penelitian yang digunakan untuk memperoleh referensi yang tepat. Prosedur penelitian ini mengacu pada langkah-langkah pokok yang ditempuh oleh peneliti dalam upaya menjawab permasalahan yang dikemukakan.

Dalam penelitian ini peneliti menggunakan pendekatan kualitatif dimana dalam penelitian ini lebih menekankan pada makna dan proses daripada hasil suatu aktivitas.

Menurut Bogdan dan Taylor (1975) yang dikutip oleh Moleong (2007:4) mendefinisikan bahwa peneliian kualitatif merupakan sebuah penelitian yang menghasilkan data deskripsi berupa kata-kata tertulis atau lisan dari orang-orang dan perilaku yang diamati.

Sedangkan Kirk dan Miller (1986:9) mendefinisikan bahwa penelitian kualitatif adalah tradisi tertentu dalam ilmu pengetahuan sosial yang secara fundamental bergantung pada pengamatan pada manusia dalam kawasannya sendiri dan berhubungan dengan orangorang tersebut dalam bahasannya dan peristilahannya.

Ditinjau dari jenis datanya pendekatan penelitian yang digunakan dalam penelitian ini adalah pendekatan kualitatif. Penelitian kualitatif bertujuan memperoleh gambaran seutuhnya mengenai suatu hal menurut pandangan manusia yang diteliti. Penelitian kualitatif berhubungan dengan ide, persepsi, pendapat atau kepercayaan orang yang diteliti dan kesemuanya tidak dapat diukur dengan angka. Sedangkan untuk jenis pendekatan dalam penelitian ini adalah deskriptif. Penelitian deskriptif yaitu penelitian yang berusaha untuk menuturkan pemecahan masalah yang ada sekarang berdasarkan data-data. Jenis penelitian deskriptif kualitatif yang digunakan pada penelitian ini dimaksudkan untuk memperoleh informasi mengenai "Penggunaan Sufiks Teki dalam Bahasa Jepang".

Adapun subjek penelitian yang digunakan dalam penelitian ini yaitu berupa majalah Her Story edisi Februari hingga Juni 2012.

Objek penelitian berupa kalimat-kaimat yang mengandung sufiks $\neg$ teki yang ada dalam majalah Her Story edisi Februari hingga Juni 2012 kumpulan kalimat-kalimat inilah yang selanjutnya akan dianalisis sesuai dengan permasalahan yang diangkat pada penelitian ini, yaitu terkait dengan nomina yang dapat melekat pada sufiks teki. 
Selain menggunakan teknik kepustakaan, pada penelitian ini juga di gunakan tehnik dokumentasi dalam proses pengumpulan data. Pengumpulan data melalui tehnik dokumentasi diartikan sebagai upaya untuk memperoleh data atau informasi berupa catatan tertulis atau gambar yang tersimpan berkaitan dengan masalah yang diteliti. Oleh karena itu penelitian ini tergolong jenis penelitian kualitatif. Dan dalam penelitian kualitatif yang menjadi instrumen utama yaitu peneliti sendiri, karena penelitilah yang mengumpulkan data, dan menganalisis data, mengidentifikasi data, menyeleksi data, dan menganalisis data.

Analisis data juga merupakan bagian terpenting dari metode ilmiah yang menyebabkan data menjadi bermakna dan berguna dalam memecahkan dan menyelesaikan masalah penelitian. Dalam menganalisis data yang diperoleh penulis harus menganalisisnya secara sistematis, disini penulis dituntut untuk menjabarkan data-data tersebut kedalam suatu unitunit, kemudian melakukan sintesa, menyususn kedalam pola, memilih serta memilah data mana yang kiranya penting dan tidak agar dapat dipahami oleh diri sendiri dan orang lain (Sugiono, 2007).

\section{Hasil dan Pembahasan}

Hasil yang diperoleh selama melakukan penelitian di beberapa majalah Her Stori edisi Februari hingga Juni serta koran Chuunichi Shinbun, maka diperoleh sebanyak 29 korpus data yang terdiri dari 26 kata bersufiks teki dengan kata dasar berjenis nomina biasa (futsuu meishi), 1 kata bersufiks teki dengan kata dasar berjenis nomina nama diri (koyuu meishi) dan 2 kata bersufiks teki dengan kata dasar berjenis nomina bilangan (sushi meishi), diantaranya adalah:

Ideorogii teki terdiri dari kata dasar ideorogi yang dibubuhi sufiks teki. Ideorogii merupakan jenis kata serapan (gairaigo) dari kata ideologi. Ideorogi dalam bahasa Indonesia berarti "ideologi" yang merupakan jenis nomina biasa (futsuu meishi), karena menyatakan sebuah peristiwa yang umum.

そこから、イデオロギー的な意味での資本主義、自由主義によるグローバル化が始まったの です。

Sokokara, Ideorogii teki na imi de no shihon shugi、 jiyuu shugi ni yoru gurubaru ka ga hajimatta no desu.

Dari sanalah, kapitalisme dalam arti ideologis, globalisasi liberalism dimulai.

(Her Story edisi Februari, halaman 6)

Ideorogi $(\mathrm{N})+$ teki ideorogi teki (Adjektiva)

Ideorogi merupakan sebuah kata yang tergolong ke dalam nomina $(\mathrm{N})$ yang bersifat tidak aktif yang memiliki arti 'ideologi' . Berdasarkan kamus Kokugo Daijiten, disebutkan bahwa Ideorogi memiliki makna “観念形態思想傾/ kan’ nen kei taishisou kei kou” yang artinya bentuk ideal atau kecenderungan berpikir. Setelah ditabubuhi sufiks teki menjadi ideorogiteki maka maknanya menjadi 'ideologis' (Adjektiva), yaitu segala hal yang menyangkut ideologi. Kemudian jika dilihat kelas katanya dari kata tersebut mengalami perubahan dari nomina menjadi adjektiva, secara gramatikal makna katanya pun berubah. Jadi pada data ini sufiks teki dapat mengubah kelas kata dan makna dari sebuah kata dasar atau morfem dasar.

Shouchou teki terdiri dari kata dasar shouchou yang dibubuhi sufiks teki. Shouchou dalam bahasa Indonesia berarti 'simbol' yang merupakan jenis nomina biasa, karena menyatakan sebuah peristiwa yang umum.

象徵的にいうと、「子供の声の聞こえない村」です。

Shouchou teki ni iu to[kodomo no koe no kikoenai mura]desu.

Jika dikatakan secara simbolis [Ini adalah desa dimana anda tidak dapat mendengar suara anak-anak]

(Her Story edisi Februari, halaman 6)

Shouchou (N) + teki shouchouteki (Adjektiva)

Shouchou merupakan sebuah kata yang tergolong dalam nomina $(\mathrm{N})$ yang bersifat aktif yang memiliki arti 'simbol'. Berdasarkan Kamus Kokugo Daijiten, Shouchou memiliki makna “抽象的な思想、観念事物などを、具体的な事物によって理解しやすい形で表すこと、シン 
ボルです/ chuushou teki na shisou kan’ nen jibutsu nado o, gutai teki na jibutsu ni yotte rikai shi yasui katachi de arawasu koto, shinburu desu " yang artinya sesuatu yang mengekspresikan ide-ide abstrak, mengkhusus, yang mudah dipahami, dapat juga diartikan sebagai simbol atau lambang. Setelah dibubuhi sufiks teki menjadi shouchouteki maka maknanya menjadi 'simbolis' (Adjektiva). Simbolis dapat diartikan sebagai segala sesuatu mengenai lambang. Kemudian jika dilihat kelas katanya berubah dari nomina menjadi adjektiva, tetapi secara gramatikal maknanya berubah. Jadi pada data ini sufiks teki dapat mengubah kelas kata makna dari sebuah kata dasar atau morfem dasar.

Rekishi teki terdiri dari kata dasar rekishi yang dibubuhi sufiks teki.

Rekishi dalam bahasa Indonesia berarti 'sejarah' yang merupakan jenis nomina biasa, karena menyatakan sebuah peristiwa yang umum.

こういった歴史的な背景から台湾の人々は、本人の䋊細な技術と健全な精神を尊敬していま す。

Kou itta rekishiteki na haikei kara Taiwan no hitobito wa hon'nin no sensai na gijutsu to kanzen na seishin o songkei shite imasu.

Karena, latar belakang bersejarah ini, masyarakat Taiwan sangat menghormati teknologi baik mereka dan semangat positif mereka.

(Her Story edisi Februari, halaman 9-10)

Rekishi $(\mathrm{N})+$ teki rekishi teki (Adjektiva)

Rekishi merupakan sebuah kata yang tergolong dalam nomina $(\mathrm{N})$ yang bersifat tidak aktif yang memiliki arti ‘sejarah'. Berdasarkan Kamus Kokugo Daijiten, rekishi memiliki makna “人間社会が経てきた変遷,発展の経過。また、その記録/ ningen shakai ga hete kita hensen hatten no keika. Mata, sono kiroku" yang artinya catatan terkait kemajuan, transisi, pembangunan yang dialami umat manusia. Setelah dibubuhi sufiks teki menjadi rekishi teki maka maknanya menjadi 'bersejarah' (Adjektiva), yaitu segala yang berkaitan dengan suatu sejarah tertentu . Kemudian jika dilihat kelas katanya maka terjadi perubahan dari nomina menjadi adjektiva, begitupun dengan makna katanya yang mengalami perubahan secara gramatikal. Jadi pada data ini sufiks teki dapat mengubah kelas kata serta makna dari sebuah kata dasar atau morfem dasar.

Kaimetsu teki terdiri dari kata dasar kaimetsu yang dibubuhi sufiks teki. Kaimetsu dalam bahasa Indonesia berarti 'kehancuran' yang merupakan jenis nomina biasa, karena menyatakan sebuah peristiwa yang umum.

台湾も1999年に大地で震壊滅的な被害を受けました。

Taiwan mo 1999 nen ni dai jishin de kaimetsu teki na higai o ukemashita.

Gempa besar yang terjadi pada tahun 1999 juga menimbulkan kerusakan yang menghancurkan Taiwan.

(Her Story edisi Februari, halaman 10)

Kaimetsu $(\mathrm{N})+$ teki kaimetsu teki (Adjektiva)

Kaimetsu merupakan sebuah kata yang tergolong dalam nomina $(N)$ yang bersifat aktif yang memiliki arti 'kehancuran'. Berdasarkan Kamus Kokugo Daijiten, kaimetsu memiliki makna “すっかりだめになってしまうこと,組織などが総崩れになること/Sukkari dame ni natte shimau koto, soshiki nado ga sōkuzure ni naru koto" yang dapat diartikan sebagai bentuk kehancuran yang sepenuhnya, baik dalam organisasi ataupun hal lainnya. Setelah dibubuhi sufiks teki menjadi kaimetsu teki maka maknanya menjadi 'bersifat menghancurkan' (Adjektiva). Kemudian jika dilihat kelas katanya maka terjadi perubahan dari nomina menjadi adjektiva, begitupun dengan makna katanya yang mengalami perubahan secara gramatikal. Jadi pada data ini sufiks teki dapat mengubah kelas kata serta makna dari sebuah kata dasar atau morfem dasar.

Keizai teki terdiri dari kata dasar keizai yang dibubuhi sufiks teki. Keizai dalam bahasa Indonesia berarti 'ekonomi' yang merupakan jenis nomina biasa (futsuu meishi), karena menyatakan sebuah peristiwa yang umum.

加えて、植民地時代から台湾には日系企業が多く存在し、経済的な面においても重要な関係 を持っていることから、台湾人は非常に親日家が多いと思います。 
Kuwaete shokuminchi jidai kara Taiwan ni wa nikkei kigyou ga ooku sonzai shi keizaiteki na men ni oite mo juuyouna kankei o motte iru koto kara, Taiwan jin wa hijou ni shinnichi ka ga ooi omoimasu.

Selain itu, saya fikir banyak orang Taiwan yang sangat mendukung Jepang dikarenakan adanya hubungan yang penting dalam aspek ekonomi.

(Her Story edisi Februari , halaman 10)

Keizai $(\mathrm{N})+$ teki

keizaiteki (Adjektiva)

Keizai merupakan sebuah kata yang tergolong dalam kata benda $(\mathrm{N})$ yang bersifat tidak aktif yang memiliki arti 'ekonomi'. Berdasarkan Kamus Kokugo Daijiten, Keizai berarti “サービスを生産、分配、消費する活動 / saabisu o seisan, bunpai, shouhi suru katsudou " yang artinya sebuah kegiatan menghasilkan, mendistribusikan, dan mengkonsumsi barang. Setelah dibubuhi sufiks teki menjadi keizaiteki maka maknanya menjadi 'ekonomis' (Adjektiva), segala sesuatu yang berkaitan dengan aspek ekonomi. Kelas kata pada data ini berubah dari nomina menjadi adjektiva, dan mengalami perubahan makna secara gramatikal. Jadi pada data ini sufiks teki dapat mengubah kelas makna dari sebuah kata dasar atau morfem dasar.

Sekai teki terdiri dari kata dasar sekai yang dibubuhi sufiks teki. Sekai dalam bahasa Indonesia berarti "dunia" yang merupakan jenis nomina biasa (futsuu meishi), karena menyatakan sebuah peristiwa yang umum.

グリーンベルト運動は、「国連婦人の10年」が始まった1976年の翌7年に産声を上げ、世界 的な女性運動の広がりと共に開きます。

Guriin beruto undou wa, [kokuren fujin no 10 nen]ga hajimatta 1976 nen no yoku 7 nen ni ubugoe o age, sekaitekina josei undou no hirogari to tomoni hirakimasu

Gerakan Green Belt lahir dimulai setelah [satu dekade organisasi perempuan di PBB] dan mulai mengangkat suara 7 tahun setelah 1976 dengan bersama sama membuka dan menyebarkan gerakan wanita secara global.

(Her Story edisi Februari, Halaman 25)

Sekai $(\mathrm{N})+$ teki sekaiteki (Adjektiva)

Sekai merupakan sebuah kata yang tergolong dalam kata benda $(\mathrm{N})$ yang bersifat tidak aktif yang memiliki arti 'dunia'. Berdasarkan Kamus Kokugo Daijiten, Sekai memiliki makna

“地球上のすべての地域 / chikyuujou no subete no chiki”, yang berarti seluruh bagian di bumi. Setelah dibubuhi sufiks teki menjadi shouchouteki maka maknanya menjadi 'mendunia/global' (Adjektiva). Kelas kata pada data ini berubah dari nomina menjadi adjektiva, dan mengalami perubahan makna secara gramatikal. Jadi pada data ini sufiks teki dapat mengubah kelas kata dan makna dari sebuah kata dasar atau morfem dasar secara gramatikal.

Kiseki teki terdiri dari kata dasar kiseki yang dibubuhi sufiks teki. Kiseki dalam bahasa Indonesia berarti 'keajaiban' yang merupakan jenis nomina biasa (futsuu meishi), karena menyatakan sebuah peristiwa yang umum.

空襲で絶対死んでいるはずだったのに,

偶然にもその晚だけ浅草に泊まったおかげで、奇跡的に九死に一生をえました。

Kuushuu de zettai shinde iru hazudatta no ni guuzen ni mo sono ban dake asakusa ni tomatta okage de, kisekiteki ni kyuushi ni isshou o emashita.

Harusnya saya mati dalam serangan udara, untungnya kebetulan malam itu saya menginap di Asakusa, ajaibnya saya merasa seperti mendapatkan sembilan nyawa sekaligus.

(Her Story edisi Maret, Halaman 6)

Kiseki $(\mathrm{N})+$ teki Kisekiteki (Adjektiva)

Kiseki merupakan sebuah kata yang tergolong dalam kata benda $(\mathrm{N})$ yang bersifat tidak aktif yang memiliki arti 'keajaiban'. Berdasarkan Kamus Kokugo Daijiten, kiseki memiliki makna “常識で考えては起こりえない、不思議な出来事現象/joushiki de kangaete wa 
okorienai, fushigi na dekigoto, genshou" yang dapat diartikan sebagai peristiwa aneh yang tidak mungkin terjadi jika dipikirkan dengan akal sehat. Setelah dibubuhi sufiks teki menjadi kiseki teki maka maknanya menjadi 'ajaib' (Adjektiva). Kemudian untuk kelas kata pada data ini berubah dari nomina menjadi adjektiva, dan mengalami perubahan makna secara gramatikal. Jadi pada data ini sufiks teki dapat mengubah kelas kata makna dari sebuah kata dasar atau morfem dasar.

Kosei teki terdiri dari kata dasar kosei yang dibubuhi sufiks teki. Kosei dalam bahasa Indonesia berarti "keunikan" yang merupakan jenis nomina biasa, karena menyatakan sebuah peristiwa yang umum.

個性的な脇役とコミカルな舞台、明るい曲調の歌が映画を彩ります

Koseiteki na wakiyaku to komikaru na butai, akarui kyoukucho no uta ga eiga o irodorimasu Peran pendukung yang unik dan panggung komikal serta lagu-lagu yang ceria akan mewarnai film ini

(Her Story edisi Maret, Halaman 13)

Kosei $(\mathrm{N})+$ teki koseiteki (Adjektiva)

Kosei merupakan sebuah kata yang tergolong dalam kata benda $(\mathrm{N})$ yang bersifat tidak aktif yang memiliki arti 'keunikan' , Berdasarkan Kamus Kokugo Daijiten, kosei memiliki makna “人や物が、他と比較して異なる個性をもっているさま/ hito ya mono ga, hoka to hikakushite koto naru kosei o motte iru sama " yang artinya orang atau barang yang memiliki kepribadian yang berbeda dibandingkan dengan orang lain. Setelah dibubuhi sufiks teki menjadi koseiteki maka maknanya menjadi 'unik' (Ajektiva), yaitu bersifat khas, khusus, dan lain daripada yang lain. Kemudian untuk kelas katanya terjadi perubahan dari nomina menjadi adjektiva dan mengalami perubahan makna secara gramatikal. Jadi pada data ini sufiks teki dapat mengubah kelas kata dan makna dari sebuah kata dasar atau morfem dasar.

Hikaku teki terdiri dari kata dasar hikaku yang dibubuhi sufiks teki. Hikaku dalam bahasa Indonesia berarti 'perbandingan' yang merupakan jenis nomina biasa, karena menyatakan sebuah peristiwa yang umum.

いつもの静岡は冬でも比較的暖かく、食べ物おいしい所です。

Itsumo no Shizuoka wa fuyu demo hikaku teki atatakaku tabemono no oishii tokoro desu.

Shizuoka adalah sebuah tempat dimana makanan akan relatif hangat dan tetap enak bahkan dimusim dingin.

(Her Story edisi Maret, halaman 10)

Hikaku (N) + teki hikaku teki (Adjektiva)

Hikaku merupakan sebuah kata yang tergolong dalam kata benda $(\mathrm{N})$ yang bersifat aktif. Menurut Kamus Kokugo Daijiten, hikaku memiliki makna “二つ以上のものを互いにくらべ合わせること/ Futatsuijō no mono o tagaini kurabe awaseru koto" yang artinya membandingkan dua hal atau lebih atau membandingkan satu sama lain. Setelah dibubuhi sufiks teki menjadi hikaku teki lalu maknanya berubah menjadi 'relatif' (Adjektiva). Ini menunjukkan bahwa kelas kata pada data ini mengalami perubahan dari nomina menjadi adjektiva. Begitupun dengan makna katanya yang mengalami perubahan secara gramatikal. Jadi pada data ini sufiks teki dapat mengubah kelas kata dan makna kata dari sebuah kata dasar atau morfem dasar.

Riseiteki terdiri dari kata dasar kiseki yang dibubuhi sufiks teki. Risei dalam bahasa Indonesia berarti 'kecerdasan' yang merupakan jenis nomina biasa, karena menyatakan sebuah peristiwa yang umum.

だから、率先避難行動をとることは、回りの人たちをも動かし、助ける理性的な行動なのだ 、と片田氏は子供たちに話していた。

Dakara, sossen hinan koudou to toru kata wa, mawari ni hitotachi o mougokashi, tasukeru risei teki na koudou na no da, to Katada shi wa kodomo tachi ni hanashite ita. 
Oleh karena itu, Tuan Katada memberitahu anak-anaknya bahwa mengambil inisiatif untuk melakukan sebuah tindakan evakuasi merupakan sebuah tindakan rasional yang dapat membantu orang-orang di sekitar mereka.

(Her Story edisi Maret, halaman 12)

Risei $(\mathrm{N})+$ teki Riseiteki (Adjektiva)

Risei merupakan sebuah kata yang tergolong dalam kata benda $(\mathrm{N})$ yang bersifat tidak aktif. Menurut Kamus Kokugo Daijiten 'risei' memiliki makna “論理的、概念的に思考する能力/ ronri teki, gainen teki ni shigou suru nouryoku" yang artinya adalah sebuah kemampuan berpikir secara logis dan konseptual. Setelah dibubuhi sufiks teki menjadi riseiteki maka maknanya menjadi 'cerdas atau rasional' (Adjektiva) yang berarti sifat berpikir secara logis dan masuk akal. Kemudian untuk kelas kata pada data ini mengalami perubahan dari nomina menjadi adjektiva. Begitupun dengan makna katanya yang mengalami perubahan secara gramatikal. Jadi pada data ini sufiks teki dapat mengubah kelas kata dan makna kata dari sebuah kata dasar atau morfem dasar.

\section{Simpulan dan Saran}

Di dalam beberapa majalah majalah Her Story seri Februari hingga Juni 2012, keseluruhan ditemukan sebanyak 29 kalimat yang mengandung sufiks teki yang terdiri dari 26 kata yang memiliki kata dasar berjenis nomina biasa (futsuu meishi), meliputi: ideorogi teki, sochou teki, rekishi teki, kaimatsu teki , keizai teki, sekai teki, kiseki teki, hikaku teki, risei teki, kosei teki, kaigi teki, doutoku teki, jiritsu teki, kensetsu teki, kokumin teki, kyoukuchi teki, shakai teki, kakushin teki, dentou teki, kihon teki, hitsuzen teki, shigeki teki , kanjou teki, josei teki, chiseigaku teki, dan kouka teki. Kemudian ditemukan 1 kata yang memiliki kata dasar berjenis nomina nama diri (koyuu meishi), yaitu raten teki dan 2 kata yang memiliki kata dasar berjenis nomina bilangan (suushii meishi), yaitu ippou teki , dan ippan teki, tetapi tidak ditemukan jenis nomina kata ganti (daimeishi) di dalam sumber data yang digunakan.

Saran yang ingin disampaikan peneliti, terutam kepada pelajar bahasa Jepang dan peneliti lain yang berkeinginan untuk melakukan penelitian tentang sufiks, khususnya sufiks teki adalah Bagi peneliti lain, khususnya yang akan mengambil topik yang sama yaitu terkait dengan sufiks, maka ada baiknya melakukan penelitian mengenai sufiks yang masih jarang diteliti, seperti sufiks ko dan zai , sehinggga dapat memberikan wawasan yang lebih variatif dan mendalam lagi tentang sufiks dalam bahasa Jepang .

Bagi peneliti lain, dengan ketersediaan media lain seperti lagu, film, komik, novel berbahasa Jepang, diharapkan dapat dimanfaatkan sebaik mungkin sebagai sumber data sehingga penelitian yang dilakukan bisa lebih menarik.

\section{Daftar Pustaka}

Abdul Rahman Sholeh, Pendidikan Agama dan Pengembangn untuk Bangsa. Jakarta : PT. Raja Grafindo Persada, 2005

Santoso.Teguh. 2015. Dasar- Dasar Morfologi Bahasa Jepang. Yogjakarta : IRSYADUL FIKR

Verhaar,dkk. 2004. Asas-Asas Linguistik Umum. Yogjakarta : Gajah Mada University Press

Sutedi, Dedi, 2003, Dasar Dasar Linguistik Bahasa Jepang. Bandung : Humaniora Utama Press

Vance. 1993. Prefiks dan Sufiks. Jakarta : KesaintBlanc

Ramlan.1979. Morfologi. Yogjakarta : U.P Karyon.

Mahsun.2005. Metode Penelitian Bahasa Tahapan Strategi, Metode, dan Tekniknya.: PT. Raja Grafindo Persada

Moelong. Lexy J. Metodologi Penelitian Kualitatif, Bandung : PT.Remaja Rosdakarya, 2009 Sugiyono. 2008. Metodelogi Penelitian Kuantitatif Kualitatif dan R\&D. Bandung : Alfabeta. Nurjaya, I Gede, 2015. Bahan Ajar Pengantar Linguistik. Singaraja : FBS UNDIKSHA.

Kridalaksana, Harimurti. 1982. Pembentukan Kata dalam Bahasa Indonesia. Jakarta: PT. Gramedia 
Ba'dulu, Abdul Muis. 2005. Morfosintaksis. Jakarta: Rineka Cipta

Kamus Kokugo Daijiten Online. Tersedia pada https://dictionary.goo.ne.jp ( di akses pada 29 Juni 2019 )

Kamus Besar Bahasa Indonesia (KBBI) Online. Tersedia pada https://kbbi.web.id/makna (di akses pada 19 Juli 2019) 